Indonesian Journal of Theology 5/1 (July 2017): 99-131

\title{
TEOLOGI, STUDI BIBLIKA, DAN MISI
}

\begin{abstract}
Ailsa Baker
Abstract

Missional hermeneutics is the interpretation of Scripture as it relates to the missionary task of the church. Four elements comprise a missional hermeneutics: 1) the missional trajectory of the biblical story being the foremost element, which also underlies the other three, 2) a narrative throughout Scripture centered on Christ and intended to equip the people of God for their missional task, 3) the missional context of the reader, in which attention moves from the task of equipping to the community being equipped, a community that is active, and 4) a missional engagement with culture and the implications thereof. Through the life of God's people an alternative is offered, together with an invitation to come and join. Because the separation of theology from the mission of the church has distorted theology, all theology needs to be reformulated from the perspective of missio Dei and from the realization that the church is a sent community, missional in its very being. A missional hermeneutics bears implications upon the congregation, worship, preaching, discipleship, education, ministerial training, and the missionary task in multicultural contexts.
\end{abstract}

Keywords: missional, hermeneutics, mission Dei, mission, Scripture, theology, context, story, community, church.

\begin{abstract}
Abstrak
Hermenutik misioner adalah penafsiran Alkitab berhubungan dengan tugas misioner gereja. Uraian hermenutik misioner menuruti empat unsur: 1) tujuan misioner dari kisah Alkitab merupakan unsur utama dan yang mendasari ketiga unsur lain, 2) kisah seluruh Alkitab yang berpusat pada Kristus dan bertujuan untuk memperlengkapi umat Allah bagi tugas misioner mereka, 3) konteks misioner para pembaca, sehingga perhatian bergeser dari tugas memperlengkapi kepada komunitas yang sedang diperlengkapi, komunitas yang aktif, dan 4) perjumpaan misioner dengan kultur dan tubrukan kisah yang terjadi.
\end{abstract}


Melalui kehidupan umat Allah suatu alternatif ditawarkan bersama undangan untuk datang dan juga hidup di dalamnya. Karena memisahkan teologi dari misi gereja adalah tindakan yang telah membengkokkan keberadaan teologi, semua teologi perlu dirumuskan kembali dari perspektif missio Dei dan dari kesadaran bahwa gereja adalah umat yang diutus, misioner di dlm keberadaannya. Hermeneutik misioner berdampak pada jemaat, ibadah, pengkhotbah, pemuridan, pendidikan, seminari dan tugas bermisi dalam konteks plural.

Kata-Kata Kunci: misioner, hermenutik, missio Dei, misi, Alkitab, teologi, konteks, kisah, komunitas, gereja.

\section{Pendahuluan}

Dua puluh lima tahun yang lalu, David Bosch menulis, "Iman Kristen pada hakikatnya bersifat inkarnasional; oleh karena itu kecuali gereja memilih untuk tetap tinggal sebagai suatu keberadaan yang asing, dia harus selalu memasuki konteks" di mana dia berada. ${ }^{1}$ Banyak sekali kemajuan telah terjadi sejak itu, tetapi Bosch yang berpendapat bahwa hal yang menentukan bagi Gereja hari ini adalah hubungannya dengan inti pesan Kitab Suci ${ }^{2}$ pasti setuju dengan perkembangan dalam bidang "missional hermeneutics" yang muncul belakangan ini.

Sekarang Gereja sudah menglobal, multinasional, multikultural dan multilingual. Misi dilakukan dari mana saja ke mana saja. Hermenutik pun adalah multikultural. Perjanjian Baru sendiri dilahirkan dari revolusi hermenutik dalam pembacaan Kitab Suci Perjanjian Lama. Ketika gereja mulai hadir dalam budaya-budaya lain para rasul menyadari bahwa terdapat berbagai perspektif dalam penafsiran Kitab Suci. Dan sebagian besar Perjanjian Baru ditulis oleh mereka yang terlibat di dalam pelayanan perintisan jemaat lintas budaya.

Sebagian besar teologi biblika yang berkembang di Indonesia adalah tradisional (Reformed atau Lutheran), diwarisi dari Barat, tentu juga sudah dipengaruhi oleh gerakan karismatik dengan tekanannya pada kekristenan yang eksperiential, pengalaman akan kuasa Roh

${ }^{1}$ David J. Bosch, Transformasi Misi Kristen: Sejarah Teologi Misi Yang Mengubah dan Berubah (Jakarta: Gunung Mulia, 1997), 300.

2 David J. Bosch, "Hermeneutical Principles in the Biblical Foundation for Mission" Evangelical Review of Theology 17 (1993): 439-40; dikutip oleh Christopher J. H. Wright, The Mission of God: Unlocking the Bible's Grand Narrative (Nottingham: InterVarsity, 2006), 36. 
Kudus, penafsiran Alkitab secara harfiah, kristologi yang kuat dan misiologi yang urgen. ${ }^{3}$ Beberapa tulisan teologi kontekstual sudah diterjemahkan dan juga dikarang oleh orang Indonesia ${ }^{4}$.

Teologi di Indonesia sudah pasti harus kontekstual, juga setia kepada Firman Allah sehingga apa yang telah kita terima, kita meneruskannya kepada mereka yang dapat dipercayai yang juga cakap mengajar orang lain (2 Tim. 2:2). Dalam tulisan ini, hal yang saya ingin kemukakan adalah bahwa misi menyediakan kerangka baik bagi pendekatan hermenutik dalam cara kita membaca Alkitab, dan juga dalam hal penyusunan suatu teologi biblika. Yesus sendiri memberi petunjuk mengenai hal ini. ${ }^{5}$

"Missional Hermeneutics" atau Hermenutik Misioner ${ }^{6}$ muncul di radar saya karena saya datang ke Indonesia sebagai misionaris lebih 40 tahun yang lalu, karena sejak 20 tahun yang lalu saya mengajar Misiologi (dan beberapa mata pelajaran lain) bagi prodi S1, S2 dan S3, karena saya terlibat di dalam pelayanan Firman di mimbar gereja dan pertemuan lain, karena dalam dua tahun ini saya terlibat dalam bimbingan orang Kristen baru dari kaum pengungsi, dan juga karena sejak 16 tahun yang lalu saya menjadi mentor bagi para pelayan yang merintis jemaat lintas budaya. Jadi saya ingin menjelaskan hermenutik misioner, hubungannya dengan Firman Tuhan dan teologi dalam konteks gereja-gereja di Indonesia yang majemuk dan plural.

3 L. Grant McClung, "Theology and Strategy of Pentecostal Missions" International Bulletin of Missionary Research, (January 1988): 1-6.

4 Misalnya Emanuel Gerrit Singgih, yang menulis antara lain "Menuju Hermeneutik Kontekstual Indonesia: Menafsir Alkitab dengan Mengakui Peranan Sudut Pandang Penafsir," dalam Mengantisipasi Masa Depan (Jakarta: Gunung Mulia, 2005), 31-55; E. G. Singgih, Berteologi dalam Konteks (Jakarta dan Yogyakarta: Gunung Mulia dan Kanisius, 2000), dll.

5 Dalam percakapan-Nya dengan Cleopas dan sahabatnya (Luk. 24:25-27) dan kemudian kepada kumpulan muridNya (Luk.24:45-48; Kis.1:3-8) di mana Yesus "membuka pikiran mereka, sehingga mereka mengerti Kitab Suci," yaitu dalam terang kisah PL dan kejadian-kejadian kemudian (sebagaimana dikisahkan dalam Kis.).

"Istilah "missional hermeneutic" dipakai untuk yang pertama kalinya oleh James V. Brownson, "Speaking the Truth in Love: Elements of a Missional Hermeneutic," International Review of Mission, 83, issue 330 (1994): 479-504. Usul bagi suatu "missional hermeneutic" mulai dengan Michael D. Barram, menurut George R. Hunsberger, "Mapping the Conversation," diakese 29 April 2016, http://gocn.org/resources/newsletters/2009/01/gospel-and-our-culture. George R. Hunsberger "Proposals for a Missional Hermeneutic," Missiology, 39, vol. 3 (Juli 2011): 309-321. Karena kata "misional" belum terdapat di dalam kamus bahasa Indonesia maka saya memakai kata "misioner" (yang sudah dipakai, paling tidak, sejak terbitnya buku D. R. Maitimoe Pembangunan Jemaat Misioner (Jakarta: Institut Oikoumene Indonesia, Dewan Gereja-Gereja di Indonesia, 1978). 


\section{Hermeneutik Misioner}

Hermenutik Misioner adalah "pendekatan kepada teks biblika yang berakar di dalam keyakinan dasar bahwa Allah memiliki misi di dalam dunia dan bahwa kita membaca Kitab Suci sebagai komunitas yang terpanggil untuk ikut serta di dalam maksud dan rencana ilahi itu"7, yaitu penafsiran Alkitab berhubungan dengan tugas misioner Gereja Yesus Kristus - jemaat sebagai "hermenutik dari injil."" Penafsiran misioner ini tidak memakai metode yang baru atau berbeda. Pertanyaan-pertanyaan historis, kultural, sastera dan eksegese teologis dipertanyakan, tetapi dari perspektif yang berbeda, perspektif misi Allah dalam menebus dan memulihkan dunia yang tercemar oleh dosa.

Menurut Guder, pendekatan kepada penafsiran biblika ini berakar di dalam suatu konsensus tentang strategi rasuli ketika mereka menjalankan misi Pentakostal (Kis. 2 dan sisa kitab Kis.), yaitu perintisan komunitas-komunitas yang meneruskan kesaksian yang telah menjadikan serta membentuk mereka.' Para rasul mulai tugas penginjilan dengan proklamasi dan kesaksian. Mereka yang sudah disiapkan Roh Allah untuk menerima berita itu dikumpulkan ke dalam suatu komunitas dan diajar agar kesaksian diteruskan di dalam konteks baru. Pengertian setiap komunitas pada intinya adalah misioner.

Penulisan tentang hermenutik misioner umumnya mengikuti petunjuk Hunsberger yang mengemukakan empat pokok utama baginya: ${ }^{10}$

\section{Tujuan misioner Kisah Alkitab}

Kerangka bagi penafsiran Alkitab adalah kisah yang dikandungnya, yaitu misi Allah, serta pembentukan suatu umat yang

7 Micahel Barram, "Located Questions for a Missional Hermeneutic," diakses 29 April 2016, http:/ /gocn.org; "The Bible, Missions and Social Location: Toward a Missional Hermeneutic," Interpretation, 61, vol. 1 (Januari 2007): 42-58.

${ }^{8}$ Maksudnya, jemaat yang terdiri dari laki-laki dan perempuan yang percaya Injil, hidup menurutnya dan menjadi saksi-saksi baginya. Lesslie Newbigin, Injil dalam Masyarakat Majemuke (Jakarta: Gunung Mulia, 1993), bab ke-18. Paul G. Hiebert juga menyebut "hermeneutic community." Anthropological Insights for Missionaries (Grand Rapids: Baker, 1985), 192.

9 Darrel Guder, "Missional Hermeneutics: The Missional Authority of Scripture," Mission Focus: Annual Review, 15 (2007): 107.

10 Usul-usul Hunsberger dikemukakan di pertemuan Society of Biblical Literature pada tahun 2008, "Mapping the Conversation"; George R. Hunsberger, "Proposals for a Missional Hermeneutic." 
ikut serta di dalamnya. Pendekatan ini tidak bermaksud untuk menyangkal atau meniadakan metode lain bagi eksegese historis, sastra dan teologis. Melainkan menafsirkan perikop-perikop tertentu diletakkan di dalam kisah agung Firman Allah.

Tokoh utama model ini adalah Christopher Wright. ${ }^{11}$ Tulisannya ${ }^{12}$ menjelaskan secara mendetil

alasan-alasan untuk menafsirkan Alkitab berhubungan dengan misi Allah sebagai inti kisah alkitabiah. Menurutnya kisah Alkitab adalah kisah misi Allah! Allah telah menganugerahkan suatu kanon, susunan kisah, dogma, puisi dan nubuat yang secara keseluruhan menceritakan kisah misi Allah di dalam dan bagi seluruh dunia, kisah umat Allah yang dipanggil serta diutus oleh Allah untuk ikut serta di dalam misi-Nya itu. Maka penafsiran setiap perikop Alkitab menuntut agar kisah utamanya juga diperhatikan. Inilah hermenutik misioner. Menurut Wright:

It is not enough, however, just to say that mission has a solid biblical foundation, we also need to see that the Bible itself has its roots in mission. That is, the Bible is the product of God's engagement through God's people in God's world for God's ultimate purpose for the nations and the world. The documents which now collectively form our canon of Scripture emerged as God's people (in both testaments) wrestled with the issues thrown up by their identity, role and mission in the context of a fallen world of surrounding nations, cultures and religions. The human contexts within which the divine word was spoken were precisely the contexts of God's own revelatory and redemptive work. . . . So from beginning to end, the Bible is "missional," by its very existence and by its comprehensive message. Mission then has to be a prime hermeneutical key for own own Bible reading and teaching. ...",13

${ }^{11}$ Christopher J. H. Wright, The Mission of God; C. J. H. Wright, Misi Umat Allah: Sebuah Teologi Biblika Tentang Misi Gereja (Jakarta: Perkantas, 2011); C. J. H. Wright, Keselamatan Milik Allah Kita: Merayakan Kisah Utama Alkitab (Surabaya: Perkantas Jawa Timur, 2011). Sebagai sarjana PL, Wright lebih mampu menyampaikan suatu hermenutik misioner yang menyeluruh. Sebelumnya hubungan PL dengan misi kurang diperhatikan.

${ }^{12}$ Christopher J. H. Wright, "Truth with a Mission-Reading All Scripture Missiologically," dalam Text \& Task: Scripture and Mission, ed. Michael Parsons (Bletchley: Paternoster, 2005).

13 Christopher J. H. Wright, "Whose World? Whose Mission?,” diakses 25 April 2016, https://innovistaireland.files.wordpress.com. "Tidaklah cukup untuk berkata bahwa usaha bermisi memiliki dasar alkitabiah yang kuat, kita juga perlu menyadari bahwa Alkitab sendiri berakar di dalam misi. Maksudnya, Alkitab adalah 
Berarti, bukan hanya bahwa usaha bermisi memiliki dasar alkitabiah yang kuat, tetapi bahwa Alkitab sendiri berakar di dalam misi, karena Alkitab muncul dari perjumpaan Allah dengan dunia melalui umat Allah bagi maksud Allah yang kekal demi bangsa-bangsa dan dunia. Dengan demikian misi harus menjadi kunci hermenutik utama di dalam pembacaan dan ajaran Alkitab. Oleh sebab itu Wright tidak berbicara mengenai "dasar misi alkitabiah" tetapi mengenai "dasar misioner Alkitab itu sendiri."14 Hermenutik misioner bertujuan untuk menyelidiki misi ilahi itu, latar belakangnya dan jalannya berhubungan dengan Allah sendiri, umat Allah dan dunia Allah. Wright menyatakan bahwa

A missional hermeneutic proceeds from the assumption that the whole Bible renders to us the story of God's mission through God's people in their engagement with God's world for the sake of God's purpose for the whole of God's creation. Mission is not just one of a list of things that the Bible happens to talk about, only a bit more urgently than some. Mission is, in that much-abused phrase, "what it's all about.",15

Jadi, hermenutik misioner berasal dari asumsi bahwa seluruh Alkitab menunjuk pada kita misi Allah melalui umat Allah dalam hubungannya dengan dunia Allah, demi menjalankan kehendak Allah bagi seluruh ciptaan Allah. Sebenarnya misi adalah seluruhnya yang diceritakan Alkitab! Oleh sebab itu, "betapa berbeda semua pelajaran biblika bila Alkitab diperlakukan sebagai kitab tentang misi dari awal sampai akhir,

hasil dari perjumpaan Allah dengan dunia Allah melalui umat Allah bagi maksud Allah yang kekal demi bangsa-bangsa dan dunia . . J Jadi, dari awal sampai akhir, Alkitab bersifat misioner, baik karena ada Alkitab maupun karena beritanya yang komprehensif. Maka misi harus menjadi kunci hermenutik utama di dalam pembacaan Alkitab dan ajaran kita." (terjemahan penulis).

14 Wright, Mission, 22.

15 Christopher J. H. Wright, "Truth with a Mission: Reading All Scripture Missiologically," SBJT 15, vol. 2 (2011): 6; "seluruh Alkitab merupakan fenomena 'misioner," Wright, "Truth with a Mission," 141. "Dimensi misilah, yang seringkali terabaikan dalam penafsiran teologis modern menyatukan kedua kitab perjanjian serta menyelaraskan tema-temanya ke dalam motif tunggal ... Pendek kata, dimensi misi dalam penafsiran Kitab Suci memberi struktur kepada seluruh Kitab. Maka struktur ini harus dipertahankan dalam rumusan studi teologis Kitab Suci. Dimensi misi dari penafsiran Perjanjian Lama sebagaimana dipaparkan dalam Perjanjian Baru mencapai tujuan ini, lebih daripada tema lain mana pun." (terjemahan penulis). David Filbeck, Yes, God of the Gentiles Too: The Missionary Message of the Old Testament (Wheaton: Billy Graham Center, 1994), 10 
ditulis oleh para misionaris bagi para misionaris! Melihat isi dan maksudnya, bagaimana mungkin dipelajari dari sudut pandang lain?"16

Maksud Allah untuk memulihkan ciptaan-Nya diumumkanNya langsung setelah pemberontakan Adam dan Hawa (Kej. 3:15). Kisah misi Allah adalah apa yang Dia lakukan untuk menyampaikan kabar baik ini sampai ke ujung bumi. Aktivitas Allah untuk berkomunikasi dan menebus adalah lebih daripada sekadar rumusanrumusan tentang Allah dan dapat digambarkan sebagai kisab ${ }^{17}$ yang agung atau metanarasi ${ }^{18}$, dengan empat tahapan penting: (1) Penciptaan (Kej. 1 dan 2), (2) Kejatuhan (Kej. 3), (3) Penebusan dalam sejarah: Misi Israel (Kej. 12-Maleakhi), Misi Yesus (Kitab-kitab injil), Misi gereja (Kis. Surat-surat PB, gereja sepanjang zaman) ${ }^{19}$, dan (4) Ciptaan baru (Wahyu).

Kisah agung ini mengajak para pembaca untuk memiliki perspektif yang sama dan untuk mengerti kehidupan mereka sebagai bagian kisahnya. Firman Tuhan, kata N. T. Wright, "menawarkan suatu kisah yang adalah kisah seluruh dunia. Kisah itu adalah kebenaran publik dan universal." 20 Di dalamnya semua manusia di manapun dan kapanpun harus menemukan tempatnya. Kisah itu adalah tentang arti dan tujuan sejarah dunia. Tidak disangkal bahwa Alkitab mengklaim untuk menawarkan sebuah kisah. Tetapi masih kontroversial klaim bahwa kisah inilah kisah seluruh dunia, arti dan tujuan sejarah universal. Tetapi itulah klaim hermenutik misioner.

Sejarah manusia digambarkan juga sebagai drama dan misi Allah disebut teo-drama. ${ }^{21}$ Di dalam drama tersebut Allah, karena kasih-

16 Andrew Kirk, What Is Mission? Theological Explorations (London: Darton, Longman and Todd, 1999), 20; Apa Itu Misi? (Jakarta: Gunung Mulia, 2013).

17 Kisahnya satu, sekalipun Alkitab terdiri dari kumpulan cerita. Richard Bauckham, The Bible and Mission: Christian Mission in a Postmodern World (Carlisle: Paternoster, 2003), 92-94.

18 "Keselamatan adalah sebuah kisah penting yang mendasar . . . Keselamatan dibentuk dalam sebuah metanarasi yang menyusun wawasan dunia yang alkitabiah." Wright, Keselamatan Milik Allab Kami, 102; The Mission of God, 54-55.

19 Dengan memakai konsep Hamba Tuhan dari Yesaya bagi misiologinya, Lukas menghubungkan misi Israel, misi Yesus dan misi gereja dalam misi Allah. Perkataan Yesus dalam Yoh. 20.21 mendefinisikan identitas dan peran gereja dalam misi Allah. Michael W. Goheen, "Notes Toward a Framework for a Missional Hermeneutic" (26 November 2006), diakses 28 April 2016, http://gocn.org.

20 N. T. Wright, The New Testament and the People of God (London: SPCK, 1992), 41-42.

21 Istilah Kevin J. Vanhoozer, "One Rule to Rule Them All?," dalam Globalizing Theology: Belief and Practice in an Era of World Christianity, ed. Craig Ott dan Harold A. Netland (Grand Rapids: Baker, 2006), 109-115. Ide yang sama terdapat dalam William Dyrness, Agar Bumi Bersukacita (Jakarta: Gunung Mulia, 2001), 15; A. Scott Moreau, Gary R. Corwin dan Gary B. McGee Introducing World Missions (Grand Rapids: Baker, 2004), 27; Craig G. Bartholomew dan Michael W. Goheen, The Drama 
Nya, mengerjakan maksud misi-Nya di antara umat manusia yang tercemar oleh dosa. Drama ini disebut teo-drama karena Allahlah yang mengaturnya. Alkitab Perjanjian Lama dan Baru menyediakan naskah dan kisahnya; sejarah mencatat bagaimana orang lain pada masa lampau menafsirkan dan memainkannya; teologi misi membuat refleksi dan memberitahu peran gereja di dalamnya, khususnya tentang rencana penebusan Allah di dalam dunia dan di antara bangsa-bangsa; ilmu sosial menggambarkan panggung budaya di mana drama itu dimainkan; suara gereja global adalah baik pengkritik maupun lakon baru di dalam drama itu.

God the Father is the playwright and producer; Jesus Christ and his redemptive work is the message of the story; and the Holy Spirit is both the inspiration and the director guiding the actors. The mission theologian - an academic, a pastor or a layperson - serves as the dramaturge, who carefully studies the play and helps clarify its significance and interprets the script both for the players and for the audience. In this way the drama is enacted as the playwright intended. This drama is specifically missional in nature because it is played out on the stage of the world, not in the confines of the church or the academy. The drama will not be complete until those from every people, nation, tribe and tongue have beheld its glory and been taken up in its story line. ${ }^{22}$

Michael Goheen ${ }^{23}$ mengikuti kerangka Wright dan menekankan "urgensi dari membaca Alkitab sebagai satu kisah" secara misiologis. Walaupun pengertian tradisional akan missio Dei adalah mengenai pengutusan: Bapa mengutus Anak, Bapa dan Anak mengutus Roh dan gereja, Wright berbicara tentang missio Dei, "misi Allah," misi Trinitas ${ }^{24}$, bukan sebagai aktivitas kita, tetapi sebagai

of Scripture: Finding Our Place in the Biblical Story (Grand Rapids: Baker, 2004), 13; Kevin deYoung dan Greg Gilbert, What Is the Mission of the Church? Making Sense of Social Justice, Shalom and the Great Commission (Wheaton: Crossway, 2011), 70; Timothy C. Tennent, World Missions: A Trinitarian Missiolgy for the 21st Century (Grand Rapids: Kregel, 2010), 61.

22 Craig Ott, Pendahuluan untuk Encountering Theology of Mission, ed. Craig Ott, Stephen J. Strauss dan Timothy C. Tennent (Grand Rapids: Baker, 2010), xxiii.

23 Michael W. Goheen, A Light to the Nations: The Missional Church and the Biblical Story (Grand Rapids: Baker Academic, 2011); Introducing Christian Mission Today: Scripture, History and Issues (Downers Grove: IVP Academic, 2014).

24 J. Andrew Kirk, What Is Mission? Theological Explorations (London: Darton Longman and Todd, 1999), 27. 
"partisipasi umat Allah yang dipanggil serta diperintahkan oleh Allah, di dalam maksud dan rencana Allah di dalam sejarah dunia Allah demi penebusan seluruh ciptaan Allah." 25 Maka tidak dikatakan bahwa Allah mempunyai misi bagi gereja-Nya di dalam dunia, melainkan bahwa Allah memiliki gereja bagi misi-Nya di dalam dunia! Misi tidak diciptakan bagi gereja; gereja dijadikan bagi misi, misi Allah. ${ }^{26}$ Dalam kata lain, Misiologi mendahului Eklesiologi. Goheen menekankan bahwa misi adalah komunikasi berita injil oleh umat Allah di mana saja bukan dengan perkataan saja tetapi juga melalui kehidupan dan perbuatan mereka. ${ }^{27}$

\section{Tujuan Penulisan Alkitab}

Tujuan interpretasi biblika berfungsi untuk menggenapi tujuan tulisan-tulisan biblis, yaitu untuk memperlengkapi umat Allah bagi tugas mereka. Inilah sifat, tujuan dan maksud kitab-kitab dalam Alkitab. ${ }^{28}$ Darrell Guder, tokoh yang membicarakan hal ini, berkata: "Yesus sendiri membentuk generasi pertama orang Kristen bagi misiNya... . Setelah itu, kesaksian mereka menjadi alat bagi pembentukan komunitas terus-menerus." Maka "strategi rasuli untuk terus menerus membentuk komunitas-komunitas misioner menjadi tujuan tulisan mereka," yaitu untuk memperlengkapi jemaat bagi kesaksian. ${ }^{29}$

Hal ini terlihat di dalam surat-surat Perjanjian Baru di mana jemaat terbentuk melalui nasihat yang diberikan berhubungan dengan tantangan-tantangan yang muncul dari konteks komunitas yang menerima surat-surat rasuli. Dan hal ini, menurut Guder, adalah benar juga bagi Injil-injil. Setiap komunitas yang menerima kitab Injil adalah komunitas orang percaya, komunitas yang terbentuk oleh peristiwa Paskah. Maka melalui naratif kitab Injil jemaat diundang untuk mengikuti proses pemuridan ketika mereka mengikuti murid-murid Yesus dan menyertai Dia melalui pelayanan-Nya di bumi dalam jalan menuju salib. Di dalam proses murid-menjadi-rasul ini, pembentukan misioner sedang terjadi. Roh Allah memanggil manusia kepada Kristus, untuk menjadi pengikut dan saksi-Nya sebagai bagian ekklesia. Komunitas ini menerima kisah agung itu sebagai kisah mereka dan

25 Wright, Mission, 22-23, 67.

26 Wright, ibid, 62.

27 Sekarang misi tidak lagi dimengerti sebagai perluasan kekristenan secara geografis. Goheen, Introducing, 26.

28 Roma 15:4; 1 Timotius 3:15-16.

${ }^{29}$ Guder, "Missional Hermeneutics," 108. 
meneruskannya. $^{30}$ Dengan demikian mereka ikut berpartisipasi bersama Kristus di dalam misi-Nya. ${ }^{31}$ Guder menyimpulkan bahwa “tujuan 'firman Allah tertulis' adalah pembentukan gereja yang misioner secara terus-menerus. . . . Pembentukan ini terjadi ketika firman alkitabiah berkarya dengan kuasa dalam komunitas." "Demikianlah jemaat-jemaat diteguhkan dalam iman dan makin lama makin bertambah besar jumlahnya" (Kis. 16:5). Guder sendiri berbicara hanya mengenai tulisan Perjanjian Baru, tetapi Goheen berpendapat bahwa hal ini juga benar bagi Perjanjian Lama.

Menurut Guder konteksnya sangat berperan. Usaha hermenutik mengkombinasikan interpretasi alkitabiah dengan konteksnya. Injil selalu diterjemahkan ke dalam konteks tertentu. Tetapi dalam proses tersebut, Injil tetap sama, menjadi sambungan dari kisah yang sama, kabar baik yang sama yang saling menghubungkan setiap komunitas. Jadi bagi Guder, pertanyaan dasar yang memimpin interpretasi Alkitab sebagai kesaksian tertulis yang dipergunakan Allah untuk membentuk kita bagi kesaksian dan pelayanan, adalah: bagaimana teks ini memperlengkapi dan membentuk umat Allah bagi kesaksian misioner pada waktu itu, dan bagaimana teks ini membentuk kita bagi tugas yang sama pada hari ini? ${ }^{32}$

Masih banyak yang perlu diusahakan berhubungan dengan topik pembicaraan ini. ${ }^{33}$ Misalnya, apa sebenarnya kisah di dalam narasi biblika dan apa hubungannya dengan kita? Apa maksud tulisan biblis dalam kehidupan para pendengarnya dan apa di dalamnya yang memperlengkapi jemaat bagi tugas misioner? Dengan cara yang manakah hal itu memperlengkapi jemaat, ke arah yang mana, dalam bidang kehidupan apa dan dalam perjumpaan misioner yang manakah?

\section{Konteks Misi para Pembaca}

Agar kita memperoleh pengertian yang benar tentang teks, misi selalu perlu dihubungkan dengan tempat, lokasi sosial atau konteks yang kita tempati. Menurut Nicholas Lash, "[] f the questions to which the ancient authors sought to respond in terms available to them within

30 Contohnya jemaat Antiokhia yang dirintis akibat kesaksian para pengungsi penganiayaan dan yang kemudian mengutus tim rasuli ke wilayah yang belum mendengar berita injil.

31 Ibid, 119.

32 Ibid, 108-9; juga Darrell Guder, "Missional Hermeneutics: The Missional Vocation of the Congregation and How Scripture Shapes That Calling," Mission Focus, Annual Review 15 (2007): 125-142.

33 Termasuk mengenai berbagai macam genre, era yang berbeda-beda, kepribadian yang berbeda. Hunsberger, ibid. 
their cultural horizon are to be 'heard' today with something like their original force and urgency, they have first to be 'heard' as questions that challenge us with comparable seriousness." 34 Jadi, bilamana pertanyaan-pertanyaan, yang para pengarang zaman kuno berusaha untuk menjawab menurut apa yang tersedia bagi mereka dalam konteks kultur mereka, akan "didengar" pada hari ini dengan kuasa dan urgensi yang sama, pertanyaan-pertanyaan itu harus "didengar" sebagai pertanyaan-pertanyaan yang dengan serius menantang kita. Melihat konteksnya, jawaban yang diusahakan oleh para pengarang kuno adalah pertanyaan, isu dan problem misioner. Jadi bilamana kita akan "mendengar" teks dengan benar pada hari ini, partisipasi kita di dalam misi Allah merupakan syarat yang mutlak perlu. Hanya dengan demikian mata rohani kita terbuka untuk menafsirkan teks dengan benar. Hanya demikian akan kita ajukan pertanyaan-pertanyaan misioner yang benar kepada teks.

Sebagian besar orang Kristen dididik untuk membaca Alkitab sebagai dasar kepercayaan, juga bagi kesalehan pribadi. Hermenutik misioner mengingatkan kita bahwa Firman Allah bertujuan untuk membentuk komunitas umat Allah sebagai pelopor bagi kemajuan Injil. Pendekatan kepada pembacaan Alkitab yang benar selalu perlu memperhatikan konteks misi komunitas Kristen.

Karena Kitab Suci berfungsi untuk membentuk umat Allah, maka sudut pandang komunitas yang sedang dibentuk harus menjadi perhatian hermenutik misioner. Menurut Michael Barram, "Christian congregations caught up in the missio Dei read the Bible from a social location" 35 yang berciri khas misi. Pendekatannya ditandai oleh komitmen untuk "mengajukan pertanyaan-pertanyaan kritis yang bertujuan untuk mengungkapkan dengan setia missio Dei serta peran komunitas di dalam rencana Allah."36 Pertanyaan-pertanyaannya pastilah kontekstual: bagaimanakah gereja akan dengan setia membaca Alkitab pada hari ini? Dengan demikian, perhatian bergeser dari tugas memperlengkapi (oleh para pengarang Alkitab dan para penafsirnya)

${ }^{4}$ Nicholas Lash, "What Might Martyrdom Mean” Ex Auditu 1 (1985): 17 18; dikutip oleh Michael Goheen, "Notes Toward a Framework for a Missional Hermeneutic," 2.

35 Bahasa social location dalam studi biblika terpengaruh oleh asumsi postmodern bahwa semua komunikasi berasal dari dan tertuju kepada suatu konteks di mana para penulis / pembicara dan para pembaca / pendengar menyimpulkan, mengerti, menilai dan berpikir. Konsep ini beranggapan bahwa komunikasi yang obyektif tidak ada. Apa yang dikatakan atau ditulis serta apa yang didengar atau dibaca terbentuk oleh konteks - lokasi sosial - di mana seseorang hidup dan mendapat identitasnya.

36 Michael Barram "The Bible, Missions and Social Location: Toward a Missional Hermeneutic." 
ke komunitas yang sedang diperlengkapi. Jadi, dalam hal ini komunitas menjadi aktif, bukan penerima yang pasif.

Hal ini berarti bahwa proses hermenutik misioner terjadi di dalam komunitas. ${ }^{37}$ Secara tradisional, konteks hermenutik adalah dalam lingkup akademis (dikerjakan oleh para sarjana) dan liturgi Gereja (dilakukan oleh kaum klerus). Pembacaan Alkitab di dalam komunitas menyediakan konteks baru bagi penafsiran Firman Allah. Akibat penafsirannya di tempat yang berbeda-beda, hal-hal baru terlihat karena dalam komunitas masyarakat biasa (termasuk kaum miskin, mereka yang terpinggirkan, kaum muda, kaum perempuan) ikut berpartisipasi. Tetapi tetap diperlukan interaksi di antara ketiga lokasi ini. Barram sendiri menekankan bahwa justru lokasi komunitas sebagai umat yang diutus ke dalam dunia adalah penting. Komunitas tertentu menjadi umat Allah "pada waktu ini di tempat ini." Dan pertanyaanpertanyaannya muncul dari lokasi dan waktu tersebut. Komunitas juga bertanggung jawab atas bacaannya, dan harus terus mengevaluasi bacaan itu.

Menurut Barram, usaha untuk mengerti arti asli teks di luar dari konteks missio Dei dan komunitas yang sedang diperlengkapi untuk ikut serta dalam misi Allah, adalah kesalahan metodologis. Lagi pula, aktivitas bermisi di dalam dunia menciptakan pertanyaan-pertanyaan baru yang berinteraksi dengan Alkitab. Bagi Brownson, hal yang vital dalam hermenutik misioner adalah pembacaan teks dalam konteks lintas budaya: interaksi antara teks, pembaca dan yang "lain" yang memiliki pengertian yang berbeda. ${ }^{38}$ Seorang misionaris belajar untuk mendengarkan sebuah teks dari sudut pandang masyarakat yang dilayani. Jadi pelayanan misi menolong penafsir untuk membaca teks dari perspektif baik sebagai pengikut Kristus maupun dari perspektif mereka yang belum terjangkau dengan injil. Melalui tugas misi penafsir yang bijaksana belajar untuk mengajukan pertanyaan-pertyanyaan yang akan diajukan oleh mereka yang belum beriman.

\section{Perjumpaan Misioner ${ }^{39}$ dengan Kultur}

Inti dari perjumpaan misioner adalah tubrukan kisah yang terjadi bersama undangan untuk memandang dunia dengan cara yang baru.

\footnotetext{
${ }^{37}$ Hiebert, Anthropological, 192.

38 James V. Brownson, "A Response at SBL to Hunsberger's "Proposal," diakses 29 April 2016, www.gocn.org.

39 Istilah "perjumpaan missioner" berasal dari Lesslie Newbigin. Michael Goheen, "The Lasting Legacy of Lesslie Newbigin," diakses 27 Mei 2016, qideas.org $>$ articles $>$ the-lasting-legacy.
} 
Melalui kehidupan umat Allah dalam kisah Allah, suatu alternatif ditawarkan untuk juga datang dan hidup di dalamnya.

Perjumpaan misioner sudah terjadi di zaman Perjanjian Lama antara Israel dan bangsa-bangsa sekitar, seperti perjumpaan dengan klaim-klaim ilahi Firaun, dengan mitos-mitos yang membentuk kultur Timur Tengah Kuno, dengan berhala di Kanaan dan dengan kerajaankerajaan dunia pada zaman pasca pembuangan. Dalam literatur hikmat, pengertian kultural bangsa-bangsa disambut dan diterima. Perjumpaan misioner pada zaman Perjanjian Baru berbeda. Umat Allah adalah multietnis dan sudah tidak lagi terikat pada suatu tempat tertentu; mereka diutus kepada dan berdiam di dalam semua kultur dunia.

Brownson disebut sebagai pionir dalam pemahaman bahwa Injil berfungsi sebagai matriks interpretasi, di mana tradisi Alkitab dibawa ke dalam percakapan kritis dengan konteks tertentu. ${ }^{40}$ Modelnya berfokus pada apa yang sedang terjadi pada "saat misioner" ("missional moment") ketika para penulis Alkitab berbicara pada waktu dan tempat tertentu, khususnya ketika mereka mengambil perikop Perjanjian Lama dan memakainya dalam interaksinya dengan masa yang baru dalam konteks hidup "di dalam Kristus." Ini penting karena apa yang mereka lakukan memiliki persamaan dengan apa yang dilakukan pengikut Kristus di setiap tempat dan kultur ketika mereka memberitakan injil. Cara mereka melakukannya serta akibatnya itulah yang penting bagi pembentukan hermenutik misioner. Maksudnya, apa yang terjadi di dalam Perjanjian Baru menjadi paradigma bagi interaksi injil dengan kultur-kultur pada hari ini. Interaksi ini merupakan bagian integral panggilan dan misi gereja.

N. T. Wright menekankan bahwa injil ${ }^{41}$ bukanlah nasihat, tetapi berita - sesuatu sudah terjadi, sesuatu yang mengubah dunia-kabar yang baik, dan oleh karenanya kita dituntut supaya menjadi terlibat di dalam apa yang Allah sedang lakukan, ${ }^{42}$ dengan tujuan supaya Allah dimuliakan. Brownson setuju bahwa Injillah kabar yang baik karena

40 James V. Brownson, "Speaking the Truth in Love: Elements of a Missional Hermeneutic," dalam The Church between Gospel and Culture, eds. George Hunsberger dan Craig Van Gelder (Grand Rapids: Eerdmans, 1996), 228-259; "Speaking the Truth in Love: Elements of a Missional Heremeutic" International Review of Mission, 83, issue 330.

41 Injil adalah kabar baik bahwa di dalam kehidupan, kematian dan kebangkitan Yesus tercapailah puncak maksud penyelamatan Allah bagi dunia. Bahwa justru istilah "injil," daripada istilah lain, dipakai oleh pengarang PB bagi kabar baik ini berarti bahwa berita ini bersifat public, bahwa iman Kristen adalah berita bagi semua manusia, bahkan bagi dunia. Brownson, "Speaking the Truth in Love: Elements of a Missional Hermeneutic," 497.

42 N. T. Wright, Simply Good News: Why the Gospel Is Good News and What Makes It Good (New York: HarperOne, 2015). 
injil menawarkan anugerah Allah bagi semua kelompok tanpa pandang bulu. Sebagaimana terungkap dalam Perjanjian Baru, struktur injil adalah: panggilannya dan keputusan untuk menjadi pengikut (ada klaim); Injil mempunyai horison dengan lingkup universal; kematian dan kebangkitan Yesus Kristus dianggap paradigmatis (jalan terbuka). Hal-hal ini diakui oleh hermenutik misioner dan berfungsi sebagai kriteria yang harus memimpin setiap penafsiran baru dari pesan alkitabiah di mana saja dan kapan pun. ${ }^{43}$

Ross Wagner disebut sebagai contoh penting dalam hal ini. Dari surat kepada jemaat-jemaat Romawi, dia melihat bahwa Paulus adalah seorang missionary theologian dan hermeneutic theologian. Misi rasulinya diperkenalkannya sebagai misi yang memproklamasikan dan menafsirkan injil dan tradisi Kitab Suci Israel untuk merintis dan memelihara komunitas-komunitas yang muncul akibat anugerah dan kasih Allah dalam Yesus Kristus. ${ }^{44}$ Kesimpulannya:

[The] complex and dynamic interrelationship of scripture, theology, and mission within a particular cultural and historical context is nowhere more evident than in Paul's re-telling of Israel's story in Romans 9-11. . . Paul revises the scriptural story to give Gentiles a prominent part in the drama of Israel's restoration. In so doing, he even goes so far as to cast Gentiles in a role originally written for Israel. ${ }^{45}$

Wagner melihat bahwa rasul Paulus menyediakan tempat strategis bagi orang bukan Yahudi dalam drama kisah pemulihan Israel yang diceriterakan kembali dalam Roma 9-11. Kesaksian injil yang mengalami kontekstualisasi pada zaman ini pun seperti hal di atas! ${ }^{46}$

Seperti interaksi injil dengan masyarakat dalam budaya yang menekankan rasa malu (aib) dan disibukkan dengan ritus-ritus

\footnotetext{
43 James V. Brownson, "A Response at SBL to Hunsberger's "Proposals" dan Johnson, "Speaking the Truth in Love: Elements of a Missional Hermeneutic," 499-500.

44 J. Ross Wagner, Heralds of the Good News: Isaiah and Paul "In Concert" in the Letter to the Romans (Boston: Brill, Good News.

2002), 1, diakses 26 Mei 2016, https://books.google.co.id Heralds of the

45 Ibid, 357; juga Donald Robinson, "No Boasting over the Natural Branches: Gentile Circumspection in the Divine Economy," dalam The Gospel to the Nations: Perspectives on Paul's Mission, ed. Peter Bolt dan Mark Thompson (Leicester: InterVarsity, 2000), 165.

46 Hunsberger melihat bahwa pandangan Brownson dan contoh dari Wagner memiliki kemiripan dengan beberapa model misiologis yang dikembangkan oleh Newbigin, Walls, Schreiter, Sanneh, Bosch, Bevans, and Bediako. "Mapping the Conversation," 11.
} 
pentahiran, tanpa kepastian bahwa segala usaha mereka diterima. Bagi mereka, bahwa Yesus mati untuk menghapuskan aib, rasa takut, keterasingan dan kenajisan (bukan hanya untuk mengampuni dosa) menjadi kabar yang baik. Alkitab mengandung banyak metafora yang menggambarkan anugerah Allah yang memindahkan manusia dari posisi aib menjadi bersih dan terhormat. ${ }^{47}$

Maka, "misi umat Allah berarti suatu perjumpaan misioner dengan kultur, di mana hal-hal yang baik disambut dan penyembahan berhala yang terdapat di dalam semua kultur ditantang." 48 Menurut Brownson justru faktor lintas budayalah yang penting dalam hermenutik misioner karena kuasa injil untuk mentransformasi kehidupan manusia terlihat paling jelas ketika manusia dari kultur yang berbeda-beda menemukan kesatuan di dalam Kristus. ${ }^{49}$ Bahkan, menurutnya hermenutik misioner dimulai dengan asumsi bahwa kehadiran Allah di antara orang percaya adalah multi-kultural tak terreduksikan. ${ }^{50}$

Jadi, di mana kritik Alkitab tradisional bertanya, hermenutik manakah yang paling kualified untuk mengerti Kitab Suci? namun hermenutik misioner bertanya: komunitas seperti apa yang dibentuk oleh suatu hermenutik yang setia pada Firman Allah? Hermenutik misioner bertujuan untuk memberdayakan jemaat tertentu sehingga jemaat itu mampu menjalankan kehidupan berjemaat dengan setia serta bersaksi di dalam kehidupannya sehari-hari di tempat masing-masing warganya di dalam masyarakat. Menurut Hunsberger, hal ini terjadi melalui empat pertanyaan: ${ }^{51}$

1) Apa inti kisah naratif biblika dan hubungannya dengan kita? (missio Dei)

47 David A. deSilva Honor, Patronage, Kinship, Purity: Unlocking New Testament Culture (Downers Grove: InterVarsity, 2000); Bruce J. Malina, The New Testament World: Insights from Cultural Anthropology, Edisi revisi (Louisville: Westminster John Knox, 1993); Hannes Wiher, Shame and Guilt: A Key to Cross-Cultural Ministry (Hamburg: Hanssler Verlag, 2006); Werner Mischke, The Global Gospel: Achieving Missional Impact in Our Multicultural World (Scottsdale: MissionONE Resources, 2015); Timothy C. Tennent, Theology in the Context of World Christianity: How the Global Church Is Influencing the Way We Think About and Discuss Theology (Grand Rapids: Zondervan, 2007); Marvin J. Newell, Crossing Cultures in Scripture (Downers Grove: InterVarsity, 2016); Jayson Georges dan Mark D. Baker, Ministering in Honor-Shame Cultures: Biblical Foundations and Practical Essentials (Downers Grove: InterVarsity, 2016).

48 Goheen, "Notes Toward a Framework."

49 Brownson, "A Response at SBL to Hunsberger's 'Proposals . . . Essay"

50 Brownson, "Speaking the Truth in Love: Elements of a Missional Hermeneutic," 485.

${ }^{51}$ Demikian menurut Hunsberger, "Mapping the Conversation." 
2) Apa tujuan tulisan-tulisan biblis dalam kehidupan para pendengarnya? (untuk memperlengkapi kesaksian).

3) Bagaiamana gereja membaca Alkitab dengan setia pada hari ini? (pertanyaan-pertanyaan kontekstual).

4) Apa yang memimpin pemakaian kanon di dalam konteks kita? (matriks injil)

Hermenutik misioner harus mencakup segala perspektif dan konteks yang didalamnya manusia membaca teks Alkitab. Berarti Gereja global memiliki hermenutik yang kaya dalam variasinya!

\section{Misi dan Alkitab}

Elisabeth Schuessler Fiorenza ${ }^{52}$ memperhatikan bahwa, karena berbagai alasan, propaganda religius, misi dan apolgetika tidak merupakan topik kesukaan di panggung religius kontemporer saat ini, dan isu-isu ini terabaikan dalam kesarjanaan biblika. ${ }^{53}$ Tetapi akibat perubahan-perubahan luar biasa yang terjadi di

Dunia Mayoritas sepanjang abad ke-20, hal ini sudah mulai berubah. Alkitab mulai dipelajari kembali untuk mengerti apa yang dikatakannya tentang misi.

Yesus memberi teladan. Dia bukan hanya mengerti misi-Nya sendiri dari Kitab Suci Perjanjian Lama, tetapi Dia mendidik para murid-Nya untuk melihat misi mereka dengan cara yang sama dan atas dasar yang sama. Lukas 24 menceritakan tentang dua murid Yesus (Kleopas dan sahabatnya), yang pada hari kebangkitan sedang dalam perjalanan pulang ke Emaus dari Yerusalem. Mereka baru menyaksikan penyaliban dan penguburan guru mereka, Yesus Kristus. Dalam suasana keputusasaan (harapan bagi mesias yang akan membebaskan bangsa Israel sudah hancur) bercampur kebingungan (setelah mendengar laporan bahwa kuburan-Nya sudah kosong), mereka

52 Elisabeth Schüssler Fiorenza, Miracles, Mission, and Apologetics: An Introduction, Aspects of Religious Propaganda in Judaism and Early Christianity, ed. Elisabeth S. Fiorenza (South Bend: University of Notre Dame Press), 1. Dikutip oleh Michael Goheen, "Bible and Mission: Missiology and Biblical Scholarship in Dialogue," dalam Christian Mission: Old Testament Foundations and New Testament Developments, ed. Stanley E. Porter dan Cynthia Long Westfall, McMaster New Testament Studies 1 (Eugene: Wipf and Stock, 2010), 208-235.

53 Buku teologi terbaru di Indonesia, Berteologi Abad XXI: Menjadi Kristen Indonesia di Tengah Masyarakat Majemuk, ed. Jan A. Boersema, Henk Venema, Yoel Indrasmoro (Jakarta: Perkantas, 2015) tidak membicarakan Penginjilan dan Misi (tugas utama gereja), Apologetika atau Kontekstualisasi. Maka judul dan subjudulnya adalah keliru, menurut penulis. 
bercakap-cakap. Seorang (Yesus, tetapi mereka belum sadar bahwa itu Dia) datang dan berjalan bersama mereka. Mendengar pembicaraan mereka, mereka ditegur (ayat 25-27):

"Hai kamu orang bodoh, betapa lambannya hatimu, sehingga kamu tidak percaya segala sesuatu, yang telah dikatakan para nabi! Bukankah Mesias harus menderita semuanya itu untuk masuk ke dalam kemuliaanNya?" Lalu Yesus menjelaskan kepada mereka apa yang tertulis tentang Dia dalam seluruh Kitab Suci, mulai dari kitab-kitab Musa dan segala kitab nabinabi."

Perikop Kitab Suci yang dipilih Yesus tidak disebut tetapi kata "menjelaskan," yang berarti "menerjemahkan, menjelaskan, menafsirkan" menandakan bahwa Yesus memilih perikop-perikop yang "mesianik" sehingga mereka mengerti arti peristiwa-peristiwa yang baru mereka saksikan itu.

Beberapa jam kemudian kumpulan murid di Yerusalem juga mendapat kunjungan dari Yesus. Dia memberi mereka seminar hermenutik Perjanjian Lama, tentang apa yang dikatakan tentang Dia di dalam kitab Taurat Musa, kitab nabi-nabi dan kitab Mazmur.

Ia membuka pikiran mereka, sehingga mereka mengerti Kitab Suci. Kata-Nya kepada mereka: "Ada tertulis demikian: Mesias harus menderita dan bangkit dari antara orang mati . . . dalam nama-Nya berita tentang pertobatan dan pengampunan dosa harus disampaikan kepada segala bangsa, mulai dari Yerusalem. Kamu adalah saksi dari semuanya ini ... [setelah] diperlengkapi dengan kekuasaan dari tempat tinggi" (Lukas 24:45-48).

Penjelasan Yesus berarti bahwa tujuan seluruh Perjanjian Lama diringkaskan menjadi dua, yakni bahwa Mesias harus menderita, mati dan bangkit, dan juga bahwa Injil harus diberitakan ke segala bangsa. Kisah Perjanjian Lama menuju baik kepada Mesias maupun kepada Misi. Dengan cara demikian, para murid harus membaca Kitab Suci mereka.

Hal ini berarti bahwa bukan hanya penderitaan, kematian dan kebangkitan Yesus terjadi berdasarkan nubuat-nubuat Kitab Suci, tetapi juga bahwa misi gereja didasarkan Kitab Suci. Jadi, setelah pencurahan Roh Kudus pada hari Pentakosta, para murid menjadi saksi Yesus dan memberitakan pengampunan dosa di dalam namaNya. Dengan demikian mandat misi, sebagaimana diceritakan Lukas, berdasarkan pada Kitab Suci Israel, Perjanjian Lama. 
Maka dapat dikatakan bahwa bila kita membaca Kitab Suci sebagaimana diajarkan Yesus kita menjadi sadar bahwa kisahnya pada hakikatnya adalah tentang misi penyelamatan Allah. Kitab Suci menyatakan bahwa Yesus adalah Mesias yang dijanjikan Allah, yang mewujudkan identitas dan misi Israel. Kitab Suci juga menyatakan bahwa Israel berada untuk menjadi "terang bagi bangsa-bangsa." Kedua kebenaran ini tidak dapat dipisahkan.

Pengakuan Petrus bahwa Yesus adalah Mesias, Anak Allah yang hidup, menjadi dasar bagi jemaat yang didirikan Yesus. Maka di dalam khotbahnya pada hari Pentakosta, yang didasarkan pada Kitab Suci Perjanjian Lama untuk menunjukkan bahwa peristiwa baik kematian maupun kebangkitan Yesus serta pencurahan Roh-Nya adalah sesuai dengan maksud dan rencana Allah, Petrus menyuruh ribuan pendengarnya yang berasal dari berbagai kultur, untuk bertobat dan memberi diri dibaptis dalam nama Yesus Kristus untuk pengampunan dosa.

Sekalipun dipakai Allah untuk menobatkan banyak orang Yahudi, namun ketika dihadapkan dengan undangan orang Italia agar datang ke rumahnya, campur tangan ilahi melalui mimpi dan suara Roh Kudus diperlukan sebelum Petrus mengatasi prasangkanya dan masuk ke dalam rumah orang bukan Yahudi itu. Khotbahnya di depan keluarga Kornelius didasarkan pada pengalamannya bersama Yesus sebagai saksi akan peristiwa penebusan serta Kitab Suci Perjajian Lama (Kis. 10:34-43).

Surat Petrus yang pertama adalah "dokumen misi" justru karena pertanyaan-pertanyaan hakiki tentang gereja dimunculkan: Bagaimanakah seharusnya orang Kristen sebagai komunitas yang memiliki gaya hidup yang berbeda, hidup di dalam masyarakat bukan Kristen ${ }^{54}$ Suratnya dialamatkan kepada komunitas bukan Yahudi yang telah dilahirkan kembali (1 Ptr. 1:3). Mereka disebut dengan panggilan umat Israel ketika umat itu dibentuk sebagai umat Allah (Kel. 19:4-6), yaitu sebagai bangsa yang terpilih, imamat rajani, bangsa yang kudus, umat kepunyaan Allah sendiri. Tujuannya adalah supaya mereka memberitakan perbuatan-perbuatan besar Allah (1 Ptr. 2:9). Penting sekali agar komunitas Kristen mengerti peran mereka sebagai kumpulan orang percaya yang menjalankan kehidupannya di depan dunia yang mengamati mereka.

${ }^{54}$ Eckhard J. Schnabel, Early Christian Mission: Paul and the Early Church, Jilid 2 (Downers Grove: InterVarsity, 2004), 1522. 
Fokus utama dari injil Yohanes adalah misi Yesus. Misi Yesuslah berada di pusat, bukan misi murid-muridNya. ${ }^{55}$ Tujuan penulisan Injil Yohanes, yakni supaya pembaca "percaya, bahwa Yesuslah Mesias, Anak Allah dan supaya [mereka] oleh iman[nya] memperoleh hidup dalam nama-Nya" (Yoh. 20:31) memiliki konotasi mempropagandakan. Yesus diutus oleh Allah Bapa (5:23, 24, 30, 37; 17:4). Demikian juga murid-murid diutus untuk meneruskan misi-Nya (20:21) dengan tugas bukan hanya untuk mengikut tetapi juga untuk "berbuah" (15:5). Bahwa Yesus disebut sebagai "Anak Domba Allah yang menghapus dosa dunia" (1:29) dan "Juruselamat dunia" (4:42) berarti bahwa misi-Nya mencakup dunia. ${ }^{56}$

Rasul Paulus, misionari, teolog dan pastor, melihat dirinya sebagai pelayan misi yang diutus khususnya kepada kaum bukan Yahudi dengan hasrat untuk merintis jemaat ${ }^{57}$ di tempat-tempat di mana Kristus belum dikenal (Rm. 15:20). Pelayanan misinya didukung oleh perannya sebagai teolog dan gembala. Walaupun Paulus, pelopor misi Kristen pertama kepada orang-orang bukan Yahudi, menerima panggilannya untuk menjadi alat Allah dan memberitakan nama-Nya kepada bangsa-bangsa lain (Kis. 9:15; 26:16-18), namun dia harus membela baik praktek misinya maupun teologi misinya di hadapan pengkritik dan penguasa. Pembelaannya berdasarkan Kitab Suci, Perjanjian Lama (Kis. 26:6-7, 22-23; 28:25-28). Misinya disamakan dengan misi internasional Hamba Allah. Mengutip Yesaya 49:6, dia menyatakan secara blak-blakan: "Sebab inilah yang diperintahkan kepada kami: 'Aku telah menentukan engkau menjadi terang bagi bangsa-bangsa yang tidak mengenal Allah, supaya engkau membawa keselamatan sampai ke ujung bumi"' (Kis. 13:47).

Para sarjana yang mempelajari teologi Paulus jarang memperhatikan fokus misionernya. ${ }^{58}$ Tetapi bagi Paulus, teologi alkitabiah adalah teologi misi, misi Allah. Atas dasar Perjanjian Lama yang mengandung teologi misi Allah bagi semua suku bangsa, Paulus membangun teologi misinya. Contohnya:

55 Andreas J. Köstenbergerberger dan Peter T. O'Brien, Salvation to the Ends of the Earth: A Biblical Theology of Mission, NSBT 11 (Downers Grove: InterVarsity, 2001), 203, 209.

56 Andreas J. Köstenbergerberger, The Missions of Jesus and the Disciples according to the Fourth Gospel (Grand Rapids: Eerdmans, 1998), 129.

57 Don N. Howell, "Mission in Paul's Epistles: Genesis, Pattern and Dynamics," dalam Mission in the New Testament: An Evangelical Approach, ed. William J. Larkin dan Joel F. Williams, American Society of Missiology Series No.27 (Maryknoll: Orbis, 1998), 73.

58 Thomas R. Schreiner, Paul Apostle of God's Glory in Christ: A Pauline Theology (Downers Grove: InterVarsity, 2001), 37. 
Dari penciptaan, Paulus melihat misi Allah sebagai kemerdekaan bagi seluruh ciptaan bersama anak- anak Allah (Rm. 8:18-27). Dan Paulus memberitakan kebangkitan mesias sebagai karunia sulung Roh, dan menyatakan bahwa di dalam Kristus ciptaan baru (2 Kor. 5:17) telah dimulai!

Dari bapa bangsa, Abraham. Paulus melihat misi Israel sebagai umat perjanjian yang terpanggil dan berada justru untuk menjadi alat Allah demi memberkati semua kaum di muka bumi (Kej. 12:3). Pengertian ini disebut sebagai injil yang diberitakan terlebih dahulu kepada Abraham (Gal. 3:6-8). Dari panggilan Abraham dan perjanjian yang diikrarkan dengan dia, injil adalah kabar baik bahwa Allah bermaksud untuk memberkati segala bangsa di dunia.

Dari para nabi. Paulus melihat maksud Allah dalam pengumpulan bangsa-bangsa agar mereka menjadi bagian umat Allah bersama dengan Israel (mis. Yes. 66:18-20), dan bahwa Israel akan dibaharui dalam iman, sesuai dengan nubuat Taurat, nabi-nabi dan kitab Mazmur (Rm. 9-11).

Lagi pula bahasa yang dipergunakan Paulus diambil dari Perjanjian Lama, misalnya: Bahasa Kultus dipakainya bagi pelayanan pemberitaan injil (yang tidak berhubungan dengan kultus) yang disebut leitourgos (Rm. 15:16) yaitu tugas imam, dan petobat-petobat bangsa non-Yahudi disebut sebagai "persembahan" yang berkenan kepada Allah. "Tanda-tanda dan mujizat-mujizat" (Rm. 15:19) adalah bahasa dari peristiwa Keluaran ${ }^{60}$ ketika Allah menebus umat-Nya dari Mesir. Bahasa Hamba (khususnya Yes. 52:15) menjadi dasar bagi ambisi Paulus untuk memberitakan injil dalam pelayanan sebagai perintis jemaat (Rm. 15:20).

Surat-surat Paulus juga merupakan bagian dari pelayanan misinya. Dia merintis jemaat-jemaat di dalam masyarakat di mana nama Yesus belum dikenal orang. Tujuannya bukan hanya pemberitaan injil, tetapi agar jemaat-jemaat dibangun dalam iman ${ }^{61}$ serta menyaksikan injil dengan tekun ${ }^{62}$ dan setia di dalam kehidupan, perbuatan dan perkataan mereka sehari-hari ${ }^{63}$ di tengah-tengah masyarakat kafir yang

59 Dengan demikian benteng di antara yang sekuler dan yang kudus sudah runtuh dan bahasa berkorban ditransformasikan. Köstenbergerberger dan O’Brien, Salvation to the Ends of the Earth, 168.

${ }^{60}$ Kel. 7:3, 9; 11:9-10; Ul. 4:34; 6:22 dst.

61 David G. Petersen, "Maturity: The Goal of Mission," dalam The Gospel to the Nations: Perepectives on Paul's Mission, ed. Peter Bolt dan Mark Thompson (Leicester: InterVarsity, 2000), 185-204.

${ }^{62}$ Schreiner, ibid, 66-8.

63 Paulus mengharapkan jemaat-jemaat baru kemudian membagikan injil yang telah mereka terima. Ed Stetzer dengan Lizette Beard, "Paul and Church Planting," dalam Robert L. Plummer dan John Mark Terry, Paul's Missionary Methods, 
menyembah berhala. ${ }^{64}$ Dickson menggambarkan panggilannya kepada kehidupan yang etis sebagai panggilan kepada "komitmen misi." "65 Agar tujuannya tercapai Paulus bersandar pada karya Roh Kudus. Dia juga mengunjungi jemaat kembali, mengirim teman sepelayanan atau menyurati mereka ${ }^{66}$. Pelayanannya bersifat misioner.

Yakobus, pemimpin jemaat dan pemimpin sidang di Yerusalem, ketika dihadapkan dengan hasil

pelayanan misi dan kenyataan bahwa orang-orang bukan Yahudi sudah percaya Yesus, melihatnya sebagai penggenapan dari nubuat para nabi (Kis. 15:14-18, mengutip Am. 9:11-2) ${ }^{67}$ dan tidak menuntut bahwa mereka harus menaati hukum adat Yahudi.

Jadi, dasar misi dalam pengertian para rasul adalah Firman Allah, Perjanjian Lama. Karena melalui Kitab Suci mereka memahami misi Allah untuk menyelamatkan, misi yang terwujud dan tergenapi di dalam Yesus, misi kabar baik yang mereka beritakan.

Allab Alkitab dinyatakan sebagai memiliki maksud dan rencana yang sedang dijalankan, baik di dalam naratif penciptaan maupun dalam kisah keselamatan sepanjang sejarah. Alkitab juga menyatakan bahwa semua manusia memiliki sebuah misi - untuk memerintah di atas ciptaan yang lain, untuk mengusahakan dan memelihara bumi.

Lagi pula, Alkitab menyatakan bahwa umat Israel memiliki sebuah misi, yakni untuk menjadi bangsa yang kudus (Kel. 19:6), umat percontohan bagi bangsa-bangsa (Ul. 4:6-7), terang bagi mereka (Yes.

(Downers Grove: IVP Academic, 2012), 186; Schnabel, Early Christian Mission, Jilid 2, 1469; Moises D. Silva, "The Truth of the Gospel: Paul's Mission according to Galatians," dalam Gospel to the Nations, 59.

${ }^{64}$ Michael Pocock, Gailyn van Rheenen dan Douglas McConnell, The Changing Face of World Missions: Engaging Contemporary Issues and Trends (Grand Rapids: Baker Academic, 2005), 323.

${ }^{65}$ J. P. Dickson, "Mission-Commitment in Ancient Judaism and the Pauline Communities: The Shape, Extent and Background of Early Christian Mission" WUNT 159 (Tubingen: Mohr Siebeck, 2003), dikutip oleh Christopher W. Sterche, "Paul's Mission as the Mission of the Church," dalam Paul's Missionary Methods, Plummer dan Terry, 85. 1 Tes.4:12; Flp. 4:5; Kol. 4:5; Tit.2:2-10, 3:1-8; 2:10, 3:1, 8. Paulus memperhatikan dampak pada mereka di luar gereja, Dean Flemming, Recovering the Full Mission of God: A Biblical Perspective on Being, Doing and Telling (Downers Grove: IVP Academic, 2013), 183.

${ }^{66}$ Paulus menjadi pionir dalam memakai surat sebagai metode instruksi bagi jemaat-jemaatnya ketika dia tidak dapat hadir di tempat mereka. Paul Barnett, Paul, Missionary of Jesus: After Jesus (Grand Rapids: Eerdmans, 2008), dikutip oleh M. David Sills, "Paul and Contextualization," dalam Plummer dan Terry, Paul's Missionary Methods, 203-4.

${ }^{67}$ Kutipan itu tidak langsung, tetapi "hasil eksegesis yang mahir," Schnabel, Early Christian Mission, Jilid 2, 1013-5. 
49:6), kerajaan imam (Kel. 19:6) serta saluran berkat Allah (Kej. 12:3) ${ }^{68}$. Kepada Israel Allah memberi Taurat-Nya, agar mereka memiliki hasrat-Nya bagi keadilan, integritas dan kasih sayang, khususnya bagi kaum terpinggirkan, miskin dan lemah. Mereka harus menjadi bukan hanya pembawa kebenaran tentang Allah yang hidup, tetapi juga umat percontohan $^{69}$ tentang bagaimana masyarakat menjalankan kehidupan menurut kehendak Allah.

Yesus muncul dengan sebuah misi. Dia mengklaim bahwa Dia diutus ke dalam dunia (Yoh. 20:21), untuk menggenapi maksud Allah bagi Israel, dan dengan demikian menyelesaikan rencana penyelamatan Allah (Yoh. 17:4).

Dan gereja digambarkan sebagai partisipan di dalam misi Allah-diutus oleh Kepala Gereja untuk memuridkan segala suku bangsa (Mat. 28:18-20), untuk menjadi berkat dan melakukan perbuatan-perbuatan baik, untuk hidup, membagikan, mengatakan dan menunjukkan Kabar Baik. ${ }^{70}$ Dan hasil dari misi penyelamatan Allah itu dirayakan ketika wakil-wakil dari setiap suku, bangsa, kaum dan bahasa berdiri di hadapan Allah disurga dan menaikkan pujian doksologis mereka (Why. 7:9-10)..$^{71}$

Jadi, dari awal hingga akhir, Alkitab bersifat misioner, baik karena Alkitab itu ada maupun karena pesannya yang komprehensif. Oleh sebab itulah misi semestinya menjadi kunci utama hermenutik, dalam pembacaan Alkitab kita dan dalam ajaran kita. Cara yang benar bagi murid-murid Yesus untuk membaca Kitab Suci mereka adalah secara mesianis dan misiologis." 72 Lagi pula Alkitab bukan saja catatan tentang misi Allah melalui umat-Nya untuk mendatangkan keselamatan bagi dunia; Kitab Suci itu sendiri adalah alat Allah agar tujuan-Nya tercapai. Perjanjian Lama bertujuan untuk "memperlengkapi" umat Allah bagi maksud misioner. Perjanjian Baru menceritakan kisah misi Allah dan kisah itu berperan dalam kehidupan gereja perdana untuk membentuk dan memperlengkapi mereka bagi panggilan misioner mereka.

68 W. J. Dumbrell, Covenant and Creation: A Theology of the Old Testament Covenants (Carlisle: Paternoster, 1984), 66, menyebut apa yang dijanjikan kepada Abraham sebagai "suatu cetak biru teologis" bagi sejarah penebusan dunia

69 John I. Durham, Exodus, Word Biblical Commentary (Waco: Word, 1987), xxi, dikutip oleh Michael W. Goheen, Light, 33.

${ }^{70}$ Flemming, Recovering the Full Mission of God.

71 Pertobatan bangsa-bangsa berada pada pusat pesan profetis kitab Wahyu. Richard Bauckman, The Climax of Prophecy (Edinburgh: T. \& T. Clark, 1993), dikutip oleh Köstenbergerberger dan O'Brien, Salvation to the Ends of the Earth, 245.

72 Christopher Wright, "Truth with a Mission-Reading All Scripture Missiologically," 144 (huruf miring sesuai aslinya). 


\section{Misi dan Teologi}

Bosch mengingatkan kita bahwa "teologi, bila dimengerti secara alkitabiah, tidak mempunyai alasan untuk hidup, kecuali secara kritis menyertai gereja dalam misinya kepada dunia." ${ }^{.73}$ Tetapi memperhatikan latar belakang teologi yang telah membentuk kita, kita dihadapkan dengan masalah ketika kita berbicara tentang misi dan doktrin, misi dan teologi bersama. Masalahnya adalah bahwa di dalam mata pelajaran Sejarah Doktrin tidak terdapat topik Misi. Sarjana Jerman, Martin Kähler, lebih 100 tahun yang lalu, ketika berbicara tentang pengembangan teologi Kristen, mengaku bahwa misi adalah "induk teologi." 74 Ketika tradisi katekismus purbakala diselidiki, ternyata bahwa gereja terbentuk oleh realita misioner yang didalamnya teologi terbentuk. Para petobat belajar katekisme, bukan hanya bagi keselamatan pribadi, tetapi sebagai ritus untuk bergabung dengan komunitas yang bersaksi dan berkumpul secara teratur. Tugas apologetika mereka bersifat misioner. Mereka belajar untuk berinteraksi dengan konteks komunitas yang sedang muncul hingga Injil dapat disampaikan. ${ }^{75}$

Tetapi di kemudian hari, akibat kristenisasi di Eropa, tematema teologis dikembangkan tanpa hubungan dengan maksud dan karya misioner Allah, atau pada keberadaan gereja demi tugas misionernya. Akibatnya, pengertian kita mengenai injil itu sendiri dan keselamatan menjadi terbatas pada berkat bagi individu secara pribadi. Dan panggilan untuk menjadi murid Kristus dan menjalankan misi sebagai saksi-Nya menjadi diabaikan. Kirk berpendapat, "memisahkan teologi dari misi gereja adalah tindakan yang membengkokkan keberadaan teologi." "'76 Dampaknya luas: pada soteriologi, eskatologi, Kristologi, otoritas Alkitab, pneumatologi. Semua doktrin menjadi seperti daftar dalil yang formatif. ${ }^{77}$

Gereja selama ini terkesan melihat tugasnya sebagai pemeliharaan kekristenan tradisional. Akibat

pendekatan hermenutik misioner, paradigma ini berubah dan gereja dilihat sebagai komunitas yang berkumpul yang terdiri dari pribadipribadi yang tersebar di dalam masyarakat, diorientasikan kepada

73 David J. Bosch, "Theological Education in Missionary Perspective." Missiology 10, vol. 1 (Januari 1982): 27, dikutip oleh Mark Laing, "Missio Dei: Some Implications for the Church,” Missiology 37, vol. 1 (Januari 2009): 95.

${ }^{74}$ Martin Kähler, [1908] dikutip oleh David Bosch, Transformasi, 22.

75 Gruder, ibid, 110, 112.

${ }^{76} \mathrm{~J}$. Andrew Kirk, The Mission of Theology and Theology as Mission (Valley Forge:

Trinity Press International, 1997), 49.

77 Gruder, Ibid, 112-3. 
tugasnya sebagai terang, garam dan ragi di dalam dunia. Dengan demikian klaim bahwa tradisi-tradisi tertentu adalah kekristenan yang normatif bergeser ke pengakuan bahwa gereja global zaman ini adalah multikultural, multi-organisasi dan multilingual dan bahwa bentengbenteng pemisahan telah diruntuhkan oleh kasih Allah dalam Kristus. ${ }^{78}$

Guder berbicara tentang missional theology daripada teologi misi. Beliau sependapat dengan Bosch bahwa semua teologi harus dirumuskan dari perspektif missio Dei dan dari kesadaran bahwa gereja adalah umat yang diutus, misioner di dalam keberadaannya. Yang dibutuhkan adalah sebuah agenda misiologis untuk teologi ketimbang sekadar sebuah agenda teologis untuk misi; karena teologi, bila dipahami dengan benar, tidak mempunyai alasan untuk berada selain daripada secara kritis menyertai missio Dei. Jadi misi haruslah menjadi "tema dari semua teologi." 79 Teologi juga perlu melihat tugasnya sebagai pemberdayaan gereja bagi kesaksian yang adalah penggilannya. Kalau demikian, setiap aspek dalam kurikulum teologi, baik dalam gereja maupun dalam seminari harus mengalami perubahan sehingga kontribusinya menghidupkan dan berguna bagi pelayanan gereja. Panggilan untuk berteologi secara demikian adalah panggilan gereja. ${ }^{80}$

\section{Konteks Indonesia}

Hermenutik misioner berdampak bagi kehidupan gereja di Indonesia dalam berbagai hal, termasuk:

Bagi gereja: Jika hermeneutik misioner ditanggapi dengan serius maka gereja-gereja di Indonesia yang sebagian besar memiliki tradisi reformed dihadapkan dengan suatu problema. Dalam tradisi mereka yang berasal di Barat tema misi terpinggirkan hingga tidak terdapat topik "misi" dan fungsi Firman Tuhan untuk membentuk komunitas misioner terabaikan. Akibatnya tema-tema teologi telah berkembang tanpa tekanan pada tujuan dan tindakan Allah yang misioner, tanpa tekanan pada tujuan gereja yang misioner atau panggilan dan perutusan orang percaya sebagai saksi Kristus. ${ }^{81}$

Sebagai pengikut Kristus, kita harus meneruskan kisah yang sama dengan kisah yang dimulai di abad pertama di Palestina. Dan kita melakukannya dengan mengajukan pertanyaan misioner pada teks. Penterjemahan yang bersifat tafsiran dan misioner adalah tugas gereja yang misioner. Karena kewajiban kita menuntut bahwa kita

\footnotetext{
78 Ibid, 117.

${ }^{79}$ David J. Bosch, Transformasi, 758.

${ }^{80}$ Lesslie Newbigin, Injil dalam Masyarakat Majemuk.

${ }^{81}$ Guder, "Missional Hermeneutics" Mission Focus, 109-110.
} 
memberitakan injil yang sama dan menjalankan misi yang dimandatkan kepada kita, kita terus menerus bertanya, Bagaimana teks ini terus mewujudkan pembentukan komunitas yang bersaksi pada waktu itu, dan bagaimana pelaksanaannya pada hari ini?

Bagi warga jemaat: Kesimpulan dari pembacaan Alkitab secara misioner adalah bahwa Allah menjalankan tujuan penyelamatan dan pemulihan melalui komunitas, melalui jemaat-jemaat. ${ }^{82}$ Maka adalah sangat urgen supaya komunitas-komunitas Kristen mendengar serta merespon sebagai komunitas yang dipanggil dan diutus bersama ke dalam dunia, dan untuk mengerti bahwa tindakan serta perbuatannya di depan dunia yang sedang mengamati merupakan kesaksian yang sangat berkuasa tentang injil Allah. Gaya hidup yang berbeda dituntut sebagai bukti pemulihan yang telah terjadi akibat panggilan menjadi pengikut Kristus. Jadi jemaat perlu bertanya, Perubahan yang bagaimana yang dituntut teks agar dalam kehidupan secara individu dan bersama mereka menjalankannya? Tantangannya agar jemaat belajar bersama untuk melihat masyarakatnya dan dunia dengan mata Yesus!

Lalu jemaat perlu diperlengkapi untuk melihat dan berjumpa dengan ladang misi di luar gereja, serta mampu memberi pertanggungan jawab tentang pengharapannya (1 Ptr. 3:15) kepada mereka di luar yang bertanya. Kesaksiannya mencakup being, doing and saying. Pertanyaan-pertanyaan yang menolong: Mengapa kitab ini ditulis? Apa bedanya konteks jemaat sekarang dan kebutuhankebutuhan misionernya? Bagaimana perikop ini menolong umat Allah pada waktu itu untuk menghargai dan menghadapi kultur mereka: cerita-cerita dan lambang-lambangnya? Apa pesan perikop ini sekarang? Bagaimana pesan perikop ini menolong kehidupan misioner umat Allah pada waktu itu? Apa peranannya sekarang?

Bagi pengkhotbah: Dihadapkan dengan kebenaran-kebenaran alkitabiah, apa misi umat Allah di Indonesia? Kesetiaan kepada Firman Allah menuntut bahwa semua kebenarannya harus dikhotbahkan, khususnya tentang misi Allah yang di dalamnya setiap anggota jemaat harus menemukan perannya. Belajar untuk membaca teks Alkitab dalam kerangka misi Allah menolong pengkomunikasian injil. Setiap teks dalam Kitab Suci berperan untuk membentuk umat Allah sebagai komunitas misioner yang ikut serta dalam misi Allah bagi dunia. Secara praktis, sang pengkhotbah bertanya: Bagaimana teks ini menolong kita

82 Dalam teks misioner 1 Petrus 2:9, “'Tetapi kamulah [jamak] bangsa yang terpilih, imamat yang rajani, bangsa yang kudus, umat kepunyaan Allah sendiri, supaya kamu [jamak] memberitakan perbuatan-perbuatan besar dari Dia, yang telah memanggil kamu [jamak] keluar dari kegelapan kepada terang-Nya yang ajaib: kamu [jamak] yang dahulu..." 
mengerti misi Allah di dalam dunia? Perubahan apakah yang diperlukan agar kita dapat menjalankannya secara bersama dan sebagai individu? Menurut teks ini, kita dipanggil untuk menjadi orang yang bagaimana?

Bagi ibadah: Ibadah alkitabiah pada intinya bersifat misioner. Tujuan pelayanan misi adalah ibadah. Tujuan kehidupan kita, menurut katekisme, adalah untuk menyembah Allah dan menikmati Dia untuk selamanya. Hermeneutik misioner menghubungkan ibadah dengan kehidupan di dalam dunia. Belajar membaca firman Allah melalui lensa misioner menempatkan misi Allah di tempat utama bagi komunitas orang percaya. Penyembahan Allah Tritunggal juga menjadi berakar di dalam maksud dan kehendak Allah bagi seluruh umat Allah dan semua ciptaan. Ibadah gereja, sebagai ciptaan Allah yang baru, merupakan kesaksian yang luar biasa bagi dunia tentang kebesaran Allah sekaligus undangan kepada mereka yang belum terjangkau untuk menjadi bagian umat Allah yang baru.

Bagi seminari: ${ }^{83}$ Karena tugas misioner merupakan tugas dasar gereja Yesus Kristus, mata kuliah Misiologi seharusnya terdapat pada inti kurikulum sekolah teologi ${ }^{84}$ Setiap spesialis teologi dan biblika juga seharusnya ditantang untuk memandang bidangnya dari sudut pandang misi. ${ }^{85}$ Alasan utama adalah karena Allah menyatakan diri sebagai Allah yang misioner. Alkitab mengandung kisah tentang misi Allah, ditulis oleh para misionaris demi misi umat Allah dan gereja. Lagi pula, pengalaman para mahasiswa teologi pasti diperkaya akibat praktek lapangan bersama pelayan perintisan jemaat lintas budaya dan mereka akan memperoleh ketrampilan yang tidak mungkin diperoleh dengan cara lain. Tujuan seminari harus berubah dari mempersiapkan sarjananya untuk pelayanan di institusi (gereja) kepada mempersiapkan pekerja bagi pelayanan misi Allah, baik di dalam maupun di luar gereja.

83 Robert Banks, Reenvisioning Theological Education; J. Dudley Woodberry, Charles Van Engen dan Edgar J. Elliston, peny. Missiological Education for the 21 $1^{\text {st }}$ Century: The Book, the Circle and the Sandals (Maryknoll: Orbis, 1996); Patricia LloydSidle dan Bonnie Sue Lewis, peny. Teaching Mission in a Global Context (Louisville: Geneva, 2001).

${ }^{84}$ Ketika penulis menyampaikan kuliah padat di "Summer School” Persetia, pada Juli 2013 banyak di antara ke-78 mahasiswa pasca sarjana dari 10 STT di Tanah Air mengaku bahwa mata kuliah "Misiologi" belum pernah diikuti.

85 " ... the systematic reflection should not only leave room for the proclamation but must make the move inescapable." Lagi, "Teologi sistematis modern memerlukan suatu appresiasi baru tentang teologi biblika - dimengerti sebagai naratif yang mengungkapkan tindakan-tindakan Allah dengan ciptaan-Nya dari Kejadian hingga Wahyu - sebagai kontrol dalam tugas penafsirannya." Mark D. Thompson, "The Missionary Apostle and Modern Systematic Affirmation," dalam Gospel to the Nations, 377. 
Bagi misiologi: Dalam abad keduapuluh telah terjadi pergeseran paradigma dalam ilmu misiologi dari pengertian misi sebagai eklesiosentris kepada pengertian yang teosentris dan Trinitarian sebagai perwujudan anugerah dan kuasa Allah akibat kehidupan, kematian dan kebangkitan Yesus. Pergeseran ini adalah dari pemeliharaan kelanjutan kekristenan tradisionil kepada kehidupan berjemaat sebagai wujud panggilan dan perutusannya untuk menjadi terang, garam dan ragi di dalam dunia sebagaimana terdapat di dalam komunitas dengan keangekaragaman bentuk, kultur dan bahasa.

Bagi pemuridan: Dalam konteks di mana orang Kristen mengikuti katekisasi tetapi tidak dimuridkan, "pemuridan merupakan isu terdepan bagi umat Allah zaman ini." ${ }^{\prime \prime 6}$ Dalam kitab-kitab Injil, panggilan bagi pemuridan datang dari Yesus, untuk berpartisipasi dalam misi-Nya, serta menaati Dia. ${ }^{87}$ Dari perspektif ini, para orang percaya yang dibentuk oleh Yesus dan dipenuhi dengan Roh, serta mengasihi Allah dan sesama, adalah mereka yang dapat menginjili dunia. Lokasi sosial (konteks) para petobat perlu diperhatikan dan pemuridan mereka disesuaikan. ${ }^{88}$

Bagi pendidikan: Hermenutik misioner menyediakan kerangka baru bagi pembelajaran. Akibat dan dampak akan sangat berbeda bilamana komunitas beriman meninggalkan paradigma sebagai pelayan yang menyediakan barang-barang rohani untuk menjadi petunjuk akan kerajaan Allah. Pendidikan Kristen berubah. Tidak lagi hanya belajar fakta-fakta tentang cerita-cerita Alkitab atau menghafal dalil-dalil kredo gereja. Tujuannya menjadi pembentukan masing-masing murid supaya menjadi manusia sesuai kehendak Tuhan, diperlengkapi untuk berperan dalam misi Allah bagi dunia di abad ke-21 ini. Kehidupan diberi tujuan baru serta semangat baru yang akan memberi kepuasan yang tak terpikirkan sebelumnya.

Misi dalam konteks plural: Sama dengan seluruh umat manusia, orang Indonesia juga mengalami dampak dari dosa dan kejahatan dalam setiap bidang hehidupan. Karya penebusan Allah melalui Salib Kristus merupakan kabar yang baik bagi setiap bidang kehidupan yang tercemar oleh dosa. Komunitas-komunitas Kristen dihendaki untuk menjadi saksi Kristus baik sebagai komunitas maupun sebagai individu-individu dalam kehidupan mereka sehari-hari. "Perjumpaan

${ }^{86}$ Alan dan Debra Hirsch, Untamed: Reactivating a Missional Form of Discipleship (Baker Academic, 2010), 23.

87 Banks, Reenvisioning, 99.

${ }^{88}$ Misalnya pemuridan para petobat dari kelompok pengungsi, yang tinggal di Indonesia selama beberapa tahun menunggu diproses visa kenegara ketiga, (juga orang Indonesia dari latar belakang kepercayaan lain) memerlukan pendekatan yang berbeda dari katekisasi yang umumnya dijalankan oleh gereja. 
misioner" ${ }^{\prime 9}$ ini bersifat lembut, tanpa paksaan atau kekerasan. Melalui kehidupan, perkataan dan perbuatan, injil ditawarkan sebagai pilihan alternatif yang menarik, bersama juga dengan undangan untuk percaya.

\section{Kesimpulan}

Tulisan ini mengemukankan pendapat bahwa bilamana kita mau mendengar apa yang Allah sedang katakan kepada umat-Nya ketika kita membaca Alkitab, maka hermenutik misioner dibutuhkan. Hermenutik misioner menolong umat Tuhan mengerti bahwa tugas teologi dan misioner bagi gereja, baik sebagai kumpulan orang percaya maupun sebagai individu di tempatnya masing-masing adalah untuk "menceritakan kisah Yesus Kristus dengan sejelas-jelasnya, dan membiarkannya menggeser kisah lain tentang dunia." " Dengan demikian, di Indonesia yang memiliki berbagai suku dan budaya yang berbeda, kuasa injil Allah untuk mentransformasikan kehidupan akan terlihat ketika komunitas Kristen mengambil tugas Israel sebagai terang bagi bangsa-bangsa, misi Yesus untuk menjadi kerajaan Allah dikenal, dan misi gereja perdana sebagai saksi Yesus, secara khusus lintas budaya. Dengan demikian gereja Kristen menjadi hermenutik dari injil dan Allah dimuliakan di dalam pelbagai budaya.

\section{Tentang Penulis}

Dr. Ailsa Barker berasal dari New Zealand, disponsori oleh Gereja Methodist Indonesia pada tahun 1974 sebagai dosen Penyakit Dalam bagi para mahasiswa kedokteran Universitas Methodist Indonesia yang berpraktek di RSU Pematang Siantar. Dari tahun 1980-1987 bekerja sebagai Internis di RS HKBP, Balige. Kembali ke New Zealand dan menyelesaikan B.Th. (Hons) di Otago University. Sejak tahun 1991 bekerja sehari-hari di Klinik Katamso, Medan, dan dari tahun 19962015 menjadi dosen Misiologi di STT GMI, Bandar Baru. Sejak menyelesaikan D.Th. (STTII, Yogyakarta) menjadi dosen Misiologi S2 dan S3 di STTII Medan, STT Paulus, STT Sumatera Utara. Juga menjadi mobilisator bagi misi dan pelayanan lintas budaya. Menikah dengan Dr. Hardi Wirawan, mempunyai dua anak perempuan yang sudah menikah dan tiga cucu.

\footnotetext{
89 Goheen, Introducing, 334-341.
}

${ }^{90}$ N. T. Wright, The New Testament and the People of God, 132. 


\section{Daftar Pustaka}

Barram, Michael. "Located Questions for a Missional Hermeneutic." Diakses 29 April 2016. Http://gocn.org.

Barram, Michael. "The Bible, Missions and Social Location: Toward a Missional Hermeneutic” Interpretation, 61, vol. 1 (Januari 2007): 42-58.

Bartholomew, Crag G. dan Michael W. Goheen. The Drama of Scripture: Finding Our Place in the Biblical Story. Grand Rapids: Baker, 2004.

Bauckham, Richard. The Bible and Mission: Christian Mission in a Postmodern World. Carlisle: Paternoster, 2003.

Bosch, David J. Transformasi Misi Kristen: Sejarah Teologi Misi Yang Mengubah dan Berubah. Jakarta: Gunung Mulia, 1997.

Brownson, James V. “A Response at SBL to Hunsberger's "Proposal." Diakses 29 April 2016. www.gocn.org.

Brownson, James V. "Speaking the Truth in Love: Elements of a Missional Hermeneutic." International Review of Mission, 83, issue 330 (1994): 479-504.

Brownson, James V. "Speaking the Truth in Love: Elements of a Missional Hermeneutic." Dalam The Church between Gospel and Culture. Disunting oleh George Hunsberger dan Craig Van Gelder. Grand Rapids: Eerdmans, 1996.

Brownson, James V. "Speaking the Truth in Love: Elements of a Missional Heremeutic" International Review of Mission, 83, issue 330.

DeSilva David A. Honor, Patronage, Kinship, Purity: Unlocking New Testament Culture. Downers Grove: InterVarsity, 2000.

deYoung, Kevin dan Greg Gilbert. What Is the Mission of the Church? Making Sense of Social Justice, Shalom and the Great Commission. Wheaton: Crossway, 2011.

Dumbrell, W. J. Covenant and Creation: A Theology of the Old Testament Covenants. Carlisle: Paternoster, 1984.

Dyrness, William. Agar Bumi Bersukacita. Jakarta: Gunung Mulia, 2001.

Filbeck, David. Yes, God of the Gentiles Too: The Missionary Message of the Old Testament. Wheaton: Billy Graham Center, 1994.

Flemming, Dean. Recovering the Full Mission of God: A Biblical Perspective on Being, Doing and Telling. Downers Grove: IVP Academic, 2013.

Georges, Jayson dan Mark D. Baker. Ministering in Honor-Shame Cultures: Biblical Foundations and Practical Essentials. Downers Grove: InterVarsity, 2016. 
Goheen, Michael W. "Bible and Mission: Missiology and Biblical Scholarship in Dialogue." Dalam Christian Mission: Old Testament Foundations and New Testament Developments, ed. Stanley E. Porter dan Cynthia Long Westfall. McMaster New Testament Studies 1. Eugene: Wipf and Stock, 2010.

Goheen, Michael W. "The Lasting Legacy of Lesslie Newbigin." Diakses 27 Mei 2016. Qideas.org>articles>the-lasting-legacy.

Goheen, Michael W. A Light to the Nations: The Missional Church and the Biblical Story. Grand Rapids: Baker Academic, 2011.

Goheen, Michael W. Introducing Christian Mission Today: Scripture, History and Issues. Downers Grove: IVP Academic, 2014.

Goheen, Michael. "Notes Toward a Framework for a Missional Hermeneutic" (26 November 2006). Diakses 28 April 2016. Http://gocn.org.

Guder, Darrel. "Missional Hermeneutics: The Missional Authority of Scripture." Mission Focus: Annual Review 15 (2007).

Guder, Darrel. "Missional Hermeneutics: The Missional Vocation of the Congregation and How Scripture Shapes That Calling," Mission Focus, Annual Review 15 (2007): 125-142.

Hiebert, Paul G. Anthropological Insights for Missionaries. Grand Rapids: Baker, 1985.

Hirsch, Alan dan Debra Hirsch, Untamed: Reactivating a Missional Form of Discipleship. Baker Academic, 2010.

Howell, Don N. "Mission in Paul's Epistles: Genesis, Pattern and Dynamics." Dalam Mission in the New Testament: An Evangelical Approach. Disunting oleh William J. Larkin dan Joel F. Williams. American Society of Missiology Series No.27. Maryknoll: Orbis, 1998.

Hunsberger, George R. "Mapping the Conversation.” Diakses 29 April 2016.

Http://gocn.org/resources/newsletters/2009/01/gospeland-our-culture.

Hunsberger, George R. "Proposals for a Missional Hermeneutic," Missiology, 39, vol. 3 (Juli 2011): 309-321.

J. Dudley Woodberry, Charles Van Engen dan Edgar J. Elliston, peny. Missiological Education for the 21 ${ }^{\text {st }}$ Century: The Book, the Circle and the Sandals. Maryknoll: Orbis, 1996.

Jan A. Boersema, Henk Venema, Yoel Indrasmoro, peny. Berteologi Abad XXI: Menjadi Kristen Indonesia di Tengah Masyarakat Majemuk. Jakarta: Perkantas, 2015.

Kirk, J. Andrew. The Mission of Theology and Theology as Mission. Valley Forge: Trinity Press International, 1997. 
Kirk, J. Andrew. What Is Mission? Theological Explorations. London: Darton, Longman and Todd, 1999.

Köstenberger, Andreas J. dan Peter T. O'Brien, Salvation to the Ends of the Earth: A Biblical Theology of Mission. New Studies in Biblical Theology 11. Downers Grove: InterVarsity, 2001.

Köstenberger, Andreas J. The Missions of Jesus and the Disciples according to the Fourth Gospel. Grand Rapids: Eerdmans, 1998.

Laing, Mark. "Missio Dei: Some Implications for the Church.” Missiology 37, vol. 1 (Januari 2009).

Lloyd-Sidle, Patricia dan Bonnie Sue Lewis, peny. Teaching Mission in a Global Context. Louisville: Geneva, 2001.

Maitimoe, D. R. Pembangunan Jemaat Misioner (Jakarta: Institut Oikoumene Indonesia, Dewan Gereja-Gereja di Indonesia, 1978).

Malina, Bruce J. The New Testament World: Insights from Cultural Anthropology. Edisi revisi. Louisville: Westminster John Knox, 1993.

McClung, L. Grant. "Theology and Strategy of Pentecostal Missions." International Bulletin of Missionary Research (January, 1988): 1-6.

Mischke, Werner. The Global Gospel: Achieving Missional Impact in Our Multicultural World. Scottsdale: MissionONE Resources, 2015.

Moreau, A. Scott, Gary R. Corwin dan Gary B. McGee. Introducing World Missions. Grand Rapids: Baker, 2004.

Newbigin, Leslie. Injil dalam Masyarakat Majemuk. Jakarta: Gunung Mulia, 1993.

Newell, Marvin J. Crossing Cultures in Scripture. Downers Grove: InterVarsity, 2016.

Ott, Craig, Introduction to Encountering Theology of Mission. Disunting oleh Craig Ott, Stephen J. Strauss dengan Timothy C. Tennent. Grand Rapids: Baker, 2010.

Petersen, David G. "Maturity: The Goal of Mission." Dalam The Gospel to the Nations: Perepectives on Paul's Mission. Disunting oleh Peter Bolt dan Mark Thompson. Leicester: InterVarsity, 2000.

Pocock, Michael, Gailyn van Rheenen, dan Douglas McConnell, The Changing Face of World Missions: Engaging Contemporary Issues and Trends. Grand Rapids: Baker Academic, 2005.

Robinson, Donald. "No Boasting over the Natural Branches: Gentile Circumspection in the Divine Economy." Dalam The Gospel to the Nations: Perspectives on Paul's Mission. Disunting oleh Peter Bolt dan Mark Thompson. Leicester: InterVarsity, 2000.

Schnabel, Eckhard J. Early Christian Mission: Paul and the Early Church. Dua jilid. Downers Grove: InterVarsity, 2004. 
Schreiner, Thomas R. Paul Apostle of God's Glory in Christ: A Pauline Theology. Downers Grove: InterVarsity, 2001.

Sills, M. David. "Paul and Contextualization." Dalam Paul's Missionary Methods. Disunting oleh Robert L. Plummer dan John Mark Terry. Downers Grove: IVP Academic, 2012.

Silva, Moises, "The Truth of the Gospel: Paul's Mission according to Galatians," dalam Gospel to the Nations, 59.

Singgih, Emanuel Gerrit. "Menuju Hermeneutik Kontekstual Indonesia: Menafsir Alkitab dengan Mengakui Peranan Sudut Pandang Penafsir." Dalam Mengantisipasi Masa Depan. Jakarta: Gunung Mulia, 2005.

Singgih, Emanuel Gerrit. Berteologi dalam Konteks. Jakarta dan Yogyakarta: BPK dan Kanisius, 2000.

Sterche, Christopher C. "Paul's Mission as the Mission of the Church" dalam Paul's Missionary Methods. Disunting oleh Robert L. Plummer dan John Mark Terry. Downers Grove: IVP Academic, 2012.

Stetzer, Ed. dan Lizette Beard, "Paul and Church Planting," dalam Paul's Missionary Methods. Disunting oleh Robert L. Plummer dan John Mark Terry. Downers Grove: IVP Academic, 2012.

Tennent, Timothy C. Theology in the Context of World Christianity: How the Global Church Is Influencing the Way We Think About and Discuss Theology. Grand Rapids: Zondervan, 2007.

Tennent, Timothy C. World Missions: A Trinitarian Missiolgy for the 21st Century. Grand Rapids: Kregel, 2010.

Vanhoozer, Kevin J. “One Rule to Rule Them All?” Dalam Globalizing Theology: Belief and Practice in an Era of World Christianity. Disunting oleh Craig Ott dan Harold A. Netland. 109-115. Grand Rapids: Baker, 2006. 109-115.

Wagner, J. Ross. Heralds of the Good News: Isaiah and Paul "In Concert" in the Letter to the Romans. Boston: Brill,

Wiher, Hannes. Shame and Guilt: A Key to Cross-Cultural Ministry. Hamburg: Hanssler Verlag, 2006.

Wright, Christoper J. H. The Mission of God: Unlocking the Bible's Grand Narrative. Nottingham: Inter-Varsity, 2006.

Wright, Christopher J. H. "Truth with a Mission - Reading All Scripture Missiologically." Dalam Text \& Task: Scripture and Mission. Disunting oleh Michael Parsons Bletchley: Paternoster, 2005.

Wright, Christopher J. H. "Truth with a Mission: Reading All Scripture Missiologically," SBJT 15, vol. 2 (2011)

Wright, Christopher J. H. "Whose World? Whose Mission?” Diakses 25 April 2016. Https://innovistaireland.files.wordpress.com. 
Wright, Christopher J. H. Keselamatan Milik Allah Kita: Merayakan Kisah Utama Alkitab. Surabaya: Perkantas Jawa Timur, 2011.

Wright, Christopher J. H. Misi Umat Allah: Sebuah Teologi Biblika Tentang Misi Gereja. Jakarta: Perkantas, 2011.

Wright, N. T. Simply Good News: Why the Gospel Is Good News and What Makes It Good. New York: HarperOne, 2015.

Wright, N. T. The New Testament and the People of God. London: SPCK, 1992. 